\title{
PENGEMBANGAN DESA MUNTIGUNUNG SEBAGAI \\ DESA WISATA BARU DI KECAMATAN KUBU \\ KABUPATEN KARANGASEM
}

\author{
I Wayan Adi Putra Ariawan \\ Prodi Magister Pariwisata Universitas Udayana \\ Email: Adiputra.ariawan90@gmail.com \\ Made Antara \\ Prodi Magister Pariwisata Universitas Udayana \\ Email: antara_unud@yahoo.com \\ I Nyoman Sukma Arida \\ Prodi Magister Pariwisata Universitas Udayana \\ Email: sukma.arida@gmail.com
}

\begin{abstract}
Muntigunung Tourism Village is currently designated as a tourist village by the Karangasem Regency Government. The reason of Muntigunung Tourism Village as a new tourism village in Karangasem Regency because Muntigunung Tourism Village has natural beauty that is still natural, a culture that is still traditional and expected to minimize the level of poverty and beggar activities carried out by the Muntigunung Tourism Village community. This research analyzes the development strategy of Muntigunung Tourism Village. The data can be described descriptively qualitatively and analyzed using SWOT analysis techniques. The research of this study indicate that the strategy S-O (strengts-opportunities) that is applied aims to use the power possessed by utilizing the opportunities that exist. The S-T Strategy (StrenghtsThreats) that is applied aims to utilize the strength that is possessed to minimize existing threats. W-O (weakness-opportunities) strategy that aims to minimize weaknesses that are owned by exploiting opportunities. W-T (Weakness-Threats) strategies are implemented to minimize weaknesses to avoid threats.
\end{abstract}

Keywords: SWOT, Development Strategy, Tourism Village 


\section{Pendahuluan}

Kepariwisataan yang ada di Pulau Bali pada perkembangannya saat ini telah menjadi Destinasi pariwisata yang paling banyak diminati oleh wisatawan mancanegara maupun wisatawan domestik. Hal ini dapat dibuktikan dengan dipilihnya Pulau Bali untuk yang ke empat kalinya sebagai World Best Award 2014 dengan kategori The Best Islands in Asia dan menjadi satu-satunya yang ada di Benua Asia sebagai 5 The Best Island in The World yang diberikan oleh majalah terbesar di New York yaitu Travel+Leisure. Perkembangan Pariwisata Pulau Bali saat ini tidak serta merta memberikan dampak yang signifikan terhadap keberadaan pariwisata bagi daerah-daerah yang terletak di Pulau Bali Timur, Pulau Bali Utara dan Pulau Bali Barat. Kurang meratanya pengembangan pariwisata yang ada di Pulau Bali Timur, Pulau Bali Utara dan Pulau Bali Barat mengakibatkan jumlah kunjungan dan long of stay wisatawan hanya terfokuskan di areal Pulau Bali Tengah dan Selatan saja. Padahal jumlah daya tarik wisata yang ada di Pulau Bali sebagaian besar terdapat di daerah Pulau Bali Timur, Pulau Bali Utara, dan Pulau Bali Barat. Salah satu contohnya adalah Kabupaten Karangasem.

Kabupaten Karangasem terletak di bagian Pulau Bali bagian timur yang memiliki potensi daya tarik wisata dan kebudayaannya. Kabupaten Karangasem juga memiliki banyak Desa dengan ciri khasnya masing-masing dan sangat cocok dijadikan sebagai sebuah Desa Wisata demi mendongkrak minat wisatawan untuk berkunjung ke Kabupaten Karangasem. Seperti yang kita ketahui saat ini desa wisata merupakan sebuah trend kepariwisataan baru yang ada di Indonesia khususnya Pulau Bali. Melihat potensi tersebut, pemerintah Kabupaten Karangasem menetapkan 20 Desa untuk dikembangkan menjadi sebuah Desa Wisata salah satunya Desa Muntigunung. 
Desa Wisata Muntigunung merupakan sebuah Desa yang terletak di Kelurahan Tianyar Barat, Kecamatan Kubu, Kabupaten Karangasem. Dipilihnya Desa Wisata Muntigunung sebagai Desa Wisata dikarenakan letaknya yang berada diantara dua lereng Gunung Agung dan Gunug Batur, keindahan alam pegunungan yang masih sangat alami dan memiliki daya tarik unggulan yaitu kegiatan trekking, kerajinan tangan dan memproduksi kacang mente dan teh bunga rossela. Desa Wisata Muntigunung juga memiliki kebudayaan yang menjadi ciri khasnya tersendiri diantaranya : Ngaben Massal yang berbeda dengan Desa lainnya yang jatuh setiap 10 tahun sekali, Dangsil, dan Beji/sumber mata air yang bernama Papad oleh Desa Wisata Muntigunung. Dikembangkannya Desa Wisata yang ada di Desa Wisata Muntigunung, diharapkan dapat meminimalisir melakukan aktifitas gelandangan dan pengemis/gepeng yang dilakukan oleh masyarakat Desa Wisata Muntigunung dan memberantas kemiskinan yang ada di Desa Wisata Muntigunung. Perkembangan kepariwisataan yang ada di Desa Wisata Muntigunung mengalami sejumlah permasalahan yaitu masyarakat Pulau Bali pada umumnya hanya mengenal dan menganggap bahwa Desa Wisata Muntigunung adalah Desa penghasil gelandangan/gepeng pengemis yang menghiasi kota-kota besar yang ada di Pulau Bali.

Seiring waktu dan kesadaran masyarakat terdahulu dan generasi muda yang sekarang, masyarakat Desa Wisata Muntigunung perlahan tapi pasti sudah meninggalkan kebiasaan menggepeng tersebut, meskipun masih ada beberapa orang yang masih menggepeng di Kota. Hal ini dapat dibuktikan dari tingkat kesadaran masyarakat Desa Wisata Muntigunung terhadap dampak buruk dari kegiatan menggepeng dan kesadaran para orang tua terhadap pentingnya pendidikan bagi generasi muda yang ada di Desa Wisata Muntigunung. Selain itu juga banyaknya generasi muda Desa Wisata Muntigunung yang berkecimpung di dunia pariwisata baik itu sebagai karyawan biasa maupun wiraswasta yaitu sebagai driver guide freelance maupun tukang ojek di areal Pariwisata Kuta Poppies Line. 
Keberadaan Desa Wisata Muntigunung sebagai sebuah desa wisata telah didukung penuh oleh Kepala Desa Tianyar Barat yaitu Bapak Gede Agung Pasrisak Juliawan yang notabene merupakan warga asli Desa Wisata Muntigunung. Desa Wisata Muntigunung dibawah kepemimpinan beliau, Desa Wisata Muntigunung telah berbenah demi merubah persepsi masyarakat Pulau Bali yang dahulu mengenal Desa Wisata Muntigunung sebagai Desa Gepeng menjadi sebuah Desa yang memiliki akan potensi wisata yang ada di Pulau Bali. Berbagai upaya telah dilakukan diantaranya berperan dalam ditetapkannya Desa Wisata Muntigunung menjadi sebuah Desa Wisata di Kabupaten Karangasem. Memanggil pulang semua masyarakat yang menggepeng dan bekerja sama dengan Dinas Sosial dan memberikan pelatihan seperti membuat kerajinan tangan/handycraft dan membuat dupa harum guna meminimalisir kegiatan mengemis yang dilakukan oleh warganya sendiri. Selain itu juga Bapak Gede Agung Pasrisak Juliawan juga membuat "pasraman" yang bernama Pasraman Jiwa Mukti. Pasraman Jiwa Mukti merupakan sebuah tempat atau wadah untuk memberikan pemahaman atau pencerahan kepada masyarakat Muntigunung yang pernah menjadi gepeng/gelandangan dan pengemis guna menumbuhkan mental warga agar tidak melakukan kegiatan gepeng kembali.

Artikel ini menganalisis potensi wisata apa yang dapat diangkat dalam mengembangkan Desa Wisata Muntigunung, Bagaimana peran stakeholder yang ada di Desa Wisata Muntigunung, dan strategi pengembangan Desa Wisata Muntigunung.

\section{Teori dan Metode}

Teori yang digunakan pada penelitian ini ada 3 teori yakni Teori 4A (attraction, accessibility, amenity dan ancilliary), Teori Stakeholder, dan Teori Manajemen Strategi. Menurut Cooper dkk (1995: 81) attraction, accessibility, amenity dan ancillary (4A) merupakan sebuah komponen daya tarik wisata yang harus dimiliki pada setiap industri pariwisata. Keempat komponen tersebut memiliki fungsi yang sangat vital 
dalam pengembangan kepariwisataan, tanpa adanya salah satu komponen tersebut akan membuat pengembangan kepariwisataan yang ada tidak berjalan dengan baik dan maksimal.

Teori stakeholder merupakan individu, sekelompok manusia, komunitas atau masyarakat baik secara keseluruhan maupun secara parsial yang memiliki hubungan serta kepentingan terhadap perusahaan (Budimanta, 2008:40). Dengan adanya stakeholder pada suatu desa wisata tentu akan terjadinya kolaborasi antar aktor yang terlibat didalamnya demi mencapai satu tujuan dan mensukseskan perkembangan kepariwisataan khususnya desa wisata yang ada di Indonesia. kolaborasi ini disebut sebagai Pentahelix dengan rumus ABCGM yang merupakan singkatan dari Academy, Bussines, Commuity, Goverment, dan Media (Slamet dkk, 2017). Pada saat ini stakeholder dengan Pentahelix model sudah banyak diterapkan dan dikatakan sukses dalam mengembangkan suatu industri pariwisata khsususnya desa wisata yang ada di Indonesia. Teori manajemen strategi adalah seni dan ilmu penyusunan, penerapan, dan pengevaluasian keputusan-keputusan lintas fungsional yang dapat memungkinkan suatu perusahaan mencapai sasarannya.

Teknik dan pengumpulan data yang dilakukan pada penelitian ini dilakukan dengan cara melakukan observasi langsung di Desa Wisata Muntigunung, wawancara secara mendalam dengan para informan seperti : Kepala Desa Tianyar Barat, Pemerintah, pengelola, Yayasan Dian Desa dan Yayasan Mitra Samya, studi dokumentasi, dan studi kepustakaan. Sumber data yang diperoleh berasal dari sumber data primer dan sumber data sukender. Sumber data primer berupa sumber data yang dikumpulkan peneliti langsung dari sumber utamanya (Kountur, 2003:63). Sumber data sekunder data yang bersumber dari laporan yang telah dibuat pihak lain yang mendukung penelitian ini (Kountur, 2008:60). Penelitian ini menggunakan metode purposive sampling yang bertujuan untuk mencari responden yang dianggap paling tahu tentang apa yang dibutuhkan, atau dia sebagai penguasa sehingga memudahkan peneliti menjelajahi objek/situasi sosial yang diteliti. 


\section{Hasil dan Pembahasan}

\section{Potensi Desa Wisata Muntigunung}

Potensi wisata merupakan salah faktor utama, layak atau tidaknya suatu daerah untuk dikembangkan menjadi sebuah Desa Wisata. Adapun potensi wisata yang dimiliki oleh Desa Wisata Muntigunung dan ditinjau dari komponen daya tarik wisata 4A yaitu Attraction, Accessibility, Amenity dan Ancilliary.

\section{a. Atraction/Atraksi}

Desa Wisata Muntigunung merupakan sebuah daya tarik wisata yang baru dikembangkan dengan menawarkan atraksi Desa Wisata. Desa Wisata Muntigunung memiliki berbagai macam jenis atraksi wisata yang menjadikan Desa Wisata Muntigunung ditetapkan menjadi sebuah Desa Wisata yang ada di Kabupaten Karangasem.

\section{Atraksi Wisata Trekking}

Atraksi wisata trekking yang ada di Desa Wisata Muntigunung merupakan sebuah daya tarik wisata unggulan yang ada di Desa Wisata Muntigunung saat ini. Para wisatawan melakukan aktifitas trekking, para wisatawan akan menemukan dan disambut dengan keindahan alam Gunung Agung, Gunung Batur dan Danau Batur. Kegiatan Atraksi Wisata Trekking Desa Wisata Muntigunung bisa dikatakan sangat berbeda dengan kegiatan atraksi wisata trekking lainnya. Diawal pengelolaannya pihak pengelola lebih mengutamakan menjual produk tersebut dengan sistem pariwisata berkelanjutan (Sustainable Development) dengan cara membatasi jumlah kunjungan wisatawan perharinya, dan menjaga kondisi alam dan lingkungan sekitar dibandingkan dengan hanya mengejar keuntungan semata. 
Strategi tersebut bisa dikatakan berhasil sampai saat ini, terbukti pada tanggal 19 September 2011 atraksi wisata trekking yang ada di Desa Wisata Muntigunung mendapatkan penghargaan Global Eco Tourism Award yang diadakan di Turku Finlandia

\section{Kerajinan Tangan Desa Wisata Muntigunung}

Desa Wisata Muntigunung merupakan suatu daerah yang kaya akan pepohonan buah lontarnya. Melihat potensi tersebut pihak pengelola yaitu Yayasan/LSM Dian Desa melibatkan masyarakat Desa Wisata Muntigunung setempat dengan cara memberikan pelatihan kepada masyarakat setempat bagaimana cara membuat kerajinan tangan yang berasal dari daun lontar seperti aneka jenis anyaman yang berasal dari daun lontar.

Semua kerajinan tersebut akan ditawarkan kepada para wisatawan yang melakukan kegiatan atraksi wisata trekking dan pihak pengelola telah melakukan kerja sama dengan pihak Hotel Association yang ada di Provinsi Bali, sehingga dapat dipasarkan di hotel berbintang yang ada di Provinsi Bali yang tergabung didalam Hotel Association seperti Fourseason Hotel and Resort, Intercontinental Hotel, Hotel Ayana, Rich Carlton Hotel dan lain-lainnya.

\section{Produksi Kacang Mente dan Olahan Bunga Rosella}

Dahulu dan hingga saat ini masyarakat Desa Wisata Muntigunung yang berprofesi sebagai petani memanfaatkan biji buah jambu mente sebagai mata pencaharian untuk diproduksi menjadi kacang mente mentah dan dijual kepada para pengepul yang datang ke rumah-rumah penduduk yang ada di Desa Wisata Muntigunung. Melihat potensi tersebut pihak Yayasan Dian Desa memanfaatkan buah jambu mente tersebut demi menunjang kebutuhan para wisatawan yang berkunjung ke Desa Wisata Muntigunung. 
Selain memproduksi kacang mente yang ada di Desa Wisata Muntigunung. Pihak pengelola Yayasan/LSM Dian Desa juga membuat gebrakan memproduksi olahan makanan dan minuman yang berasal dari Bunga Rosella seperti teh, permen dan garam. Menurut Daniel Elber selaku pihak Yayasan Dian Desa, beliau mengungkapkan bahwa kondisi cuaca panas dengan suhu $30^{\circ}-35^{\circ}$ celcius yang ada di Desa Wisata Muntigunung membuat tanaman bunga rosella dapat tumbuh subur di Desa Wisata Muntigunung.

\section{Daya Tarik Wisata Tradisi Dangsil Desa Wisata Muntigunung.}

Tradisi dangsil yang ada di Desa Wisata Muntigunung merupakan salah satu tradisi yang telah dilakukan sejak dahulu. Desa Wisata Muntigunung yang merupakan salah satu Desa Bali Aga yang ada di Provinsi Bali yang bertujuan untuk mengucap syukur kepada Sang Maha Pencipta atas hasil kebun yang berlimpah dan anugerah yang telah diberikan kepada masyarakat Desa Wisata Muntigunung. Perbedaan Tradisi Dangsil yang ada di Desa Wisata Muntigunung dengan Tradisi Dangsil yang ada di daerah lainnya yaitu Tradisi Dangsil yang ada di daerah lain perayaannya hanya dilaksakan setiap 1 tahun sekali, sedangkan Tradisi Dangsil yang ada di Desa Wisata Muntigunung ini diadakan setiap 4 kali dalam setahun.

\section{b. Accesibilty/Aksesibilitas}

Aksesibilitas yang ada di Desa Wisata Muntigunung tahun 2018 sudah mengalami perbaikan yang cukup signifikan demi mendukung perkembangan kepariwisataan yang ada di Desa Wisata Muntigunung. Pemerintah setempat sudah melakukan berbagai upaya dalam mengembangka infrastrur jalan yang ada dan mengejar ketertinggalan perbaikan jalan yang berada di daerah pelosok Desa Wisata Muntigunung. Diharapkan pada tahun 2019 seluruh ruas jalan yang ada di Desa Wisata Muntigunung sudah rampung dikerjakan dan dapat dilelaui oleh kendaraan bermotor. 


\section{c. Amenities/Fasilitas Penunjang}

Amenity/Fasilitas Penunjang pariwisata merupakan salah satu faktor pendukung dalam mengembangkan kepariwisataan khususnya Desa Wisata yang ada di Desa Wisata Muntigunung. Selain itu juga Amenity/Fasilitas Penunjang Pariwisata menjadi sebuah sarana dan prasarana bagi kebutuhan para wisatawan agar merasa nyaman saat berkunjung ke Desa Wisata Muntigunung. Pada saat ini Desa Wisata sudah memiliki fasilitas penunjang baik yang sudah berjalan maupun masih dalam tahap pembangunan dan fasilitas penunjang yaitu telekomunikasi, sumber daya listrik, rumah makan/minum, warung/supermarket, dan penginapan. Pada saat ini Desa Wisata Muntigunung telah memiliki fasilitas penginapan dan diberi nama program Rumah Desaku Menanti. Program Rumah Desaku Menanti ini merupakan bantuan dari Kementrian Sosial dan Pemerintah Kabupaten Karangasem. Program ini bertujuan untuk memberikan kesempatan kepada masyarakat Desa Wisata Muntigunung yang sebeleumnya menggepeng, akan diberdayakan sebagai pelaku pariwisata demi memenuhi kebutuhan pariwisata yang ada di Desa Wisata Muntigunung.

\section{d. Ancilliary/Kelembagaan.}

Kelembagaan yang ada di Desa Wisata pada saat ini telah disediakan oleh pihak stakeholder dan didukung penuh oleh Kelurahaan Desa Tianyar Barat dalam pengembangan kepariwisataan yang ada di Desa Wisata Muntigunung. Kelembagaan yang ada di Desa Wisata Muntigunung memiliki tugas dan tanggung jawab masing-masing dalam memajukan kehidupan masyarkat dan perkembangan kepariwisataan yang ada di Desa Wisata Muntigunung. Kelembagaan yang ada di Desa Wisata Muntigunung seperti Children For Future yang yang menjadi finance support bagi pembangunan dan kehidupan masyarakat yang ada di Desa Wisata Muntigunung. Desa Tianyar Barat yang berperan sebagai mitra bagi setiap lembaga yang ada di Desa Wisata Wisata Muntigunung, guna memberikan masukan dan arahan (sharing partner) guna membantu kehidupan masyarakat dan mendukung 
pengembangan kepariwisataan yang ada di Desa Wisata Muntigunung. Yayasan Dian Desa yang bertanggung jawab terhadap kehidupan masyarakat Desa Wisata Muntigunung agar lebih kedepannya. Selain itu juga yayasan Dian Desa ikut mengelola atraksi wisata trekking dan di bantu oleh Bapak Wayan Pica selaku guide yang ada di Desa Wisata Muntigunung. Yayasan Mitra Samya bertanggung jawab akan kebutuhan air bersih dan membangun sustainable water supply bagi masyarakat yang ada di Desa Wisata Muntigunung saat ini. Village Development Project merupakan lembaga yang berasal dari perkumpulan para dosen dan mahasiswa Falkutas Kedokteran Universitas Udayana yang peduli terhadap kesehatan masyarakat yang ada di Desa Wisata Muntigunung.

\section{Peran Stakeholder.}

Artikel ini peran stakeholder yang ada di Desa Wisata Muntigunung akan ditinjau dengan stakeholder dengan model Pentahelix. Secara singkat model Pentahelix dimaksud kolaborasi peran 5 stakeholder yang meliputi Akademisi, Bisnis, Komunitas, Pemerintah, dan Industri/Media. Peran stakeholder dengan model Pentahelix ini sudah banyak digunakan di industri pariwisata yang ada dan sudah terbukti mampu dalam mengembangkan kepariwisataan khususnya Desa Wisata.

\section{a. Akademisi}

Akademisi pada model Pentahelix merupakan seseorang yang memiliki keahlian dan berperan sebagai konseptor yang melakukan standarisasi proses bisnis serta sertifikasi produk dan ketrampilan sumber daya manusia (Slamet dkk, 2017). Peran akademisi yang ada di Desa Wisata Muntigunung berasal dari 2 Universitas Negeri yang ada di Provinsi Bali yaitu Falkultas Kedokteran Universitas Udayana dan Universitas Pendidikan Ganesha (Undiksha). Para akademisi yang berasal dari Fakultas Kedokteran Universitas Udayana diberi nama organisasi village development project dan memiliki peran seperti memberikan pelatihan dan ilmu pengetahuan kesehatan kepada masyarakat Desa Wisata Muntigunung seperti pentingnya 
kesehatan bagi kehidupan mereka. Memberikan pelatihan bagaimana hidup sehat dan pelatihan bagaimana menjaga lingkungan sekitar agar bersih dan terbebas dari penyakit. Sedangkan peran akademisi yang berasal dari Universitas Pendidikan Ganesha (Undiksha) yang tergabung dalam Kegiatan P2M bernama penelitian dan pengabdian masyarakat adalah membantu mengembangkan kepariwsataan yang ada dan mencari potensi-potensi wisata yang baru dan cocok untuk dikembangkan menjadi sebuah atraksi wisata tambahan. Selain peran akademisi yang terdiri dari para dosen Universitas Ganesha (Undiksha) juga membantu meningkatkan pengetahuan para guru SD dan SMP dalam menunjang program Muntigunung sebagai Desa Wisata.

\section{b. Bisnis}

Bisnis pada model Pentahelix merupakan seseorang yang berperan sebagai enabler. Selain itu juga bisnis berperan sebagai enabler yang menghadirkan infrastruktur, dengan mendukung perubahan pada sumber daya manusia, proses bisnis dan produk yang dihasilkan ke era digital (Slamet dkk, 2017). Pada saat ini sudah peran bisnis/perusahaan yang turut serta dalam membantu pengembangan kepariwisataan yang ada di Desa Wisata Muntigunung. Muntigunung Community Social Enterprise merupakan perusahaan non profit yang dikelola oleh LSM Yayasan Dian Desa dan Children for Future dalam membantu perkembangan kepariwisataan di Desa Wisata Muntigunung. Muntigunung Community Social Enterprise hanya bertujuan untuk membantu kehidupan yang layak dan membuka lapangan pekerjaan bagi masyarakat Desa Wisata Muntigunung yang sebelumnya menjadi pengemis beralih bekerja yang lebih bermartabat. Pekerjaan tersebut meliputi memberdayakan masyarakat dalam mengelola hasil bumi yang ada di Desa Wisata Muntigunung seperti kacang mente, bunga the rosella, kerajinan tangan untuk dijual demi mendukung kepariwisataan yang ada di Desa Wisata Muntigunung. Selain Muntigunung Community Social Enterprise, terdapat peran bisnis lain yang ada di Desa Wisata Muntigunung yaitu Duara Travel. Duara Travel merupakan perusahaan travel 
agent yang berasal dari Negara Finlandia dan bergerak dibidang jasa akomodasi penginapan bagi para wisatawan dan memberikan kesempatan bagi para wisatawan yang hendak menginap dan menikmati segala aktifitas masyarakat Desa Wisata Muntigunung. Pembagian keuntungan dari Duara Travel ini yaitu pembayaran yang dilakukan oleh para wisatawan ke Duara Travel akan dibagi sebanyak 40\% kepada pemilik rumah/tempat para wisatawan menginap, $10 \%$ ke duara contact, $10 \%$ ke kelompok Muntigunung induk dan 30\% ke perusahaan Duara Travel sendiri.

\section{c. Komunitas}

Peran Komunitas dalam di suatu daya tarik wisata khususnya desa wisata merupakan suatu keharusan keberadaannya dalam mendukung dan mensukseskan perkembangan kepariwisataan khususnya Desa Wisata. Saat ini komunitas yang ikut serta dalam mengembangkan kepariwisatan yang ada di Desa Wisata Muntigunung baik berupa ide maupun tenaga yaitu komunitas Pasraman Jiwa Mukti. Komunitas Pasraman Jiwa Mukti merupakan komunitas yang digagas oleh Kepala Desa Tianyar Barat yaitu Gede Agung Pasrisak Juliawan yang memiliki peran dalam membangun infrastuktur dan potensi yang ada di Desa Wisata Muntigunung.

\section{d. Pemerintah}

Pemerintah pada model Pentahelix memliki peran sebagai regulator. Selain sebagai regulator Pemerintah juga sekaligus berperan sebagai kontroler yang memiliki peraturan dan tanggung jawab dalam mengembangkan Desa Wisata Muntigunung (Slamet dkk, 2017). Pada saat ini peran pemerintah yang ada di Desa Wisata Muntigunung berasal dari intansi pemerintahan Dinas Pariwisata Kabupaten Karangasem dan Provinsi Bali dan Dinas Sosial Kabupaten Karangasem. Peran Dinas Pariwisata Kabupaten Karangasem dan Provinsi Bali terdiri dari memberikan seminar kepariwisata kepada masyarakat dan anggota pokdarwis Desa Wisata Muntigunung di kantor Kepala Desa Tianyar Barat dengan tema Pengembangan Desa Wisata Muntigunung Kecamatan Kubu, Kabupaten Karangasem. 
Tujuan diadakannya kegiatan seminar ini bertujuan untuk memberikan wawasan dan ilmu pengetahuan tentang kepariwisataan dalam mengembangkan kepariwisataan khususunya desa wisata dan bagaimana menjadi pelaku pariwisata yang ada di Desa Wisata Muntigunung. Kegiatan seminar tersebut diisi oleh narasumber yang bernama Djinaldi Gosana yang notabane merupakan ketua Asosiasi Komunitas Pariwisata Berbasis Masyarakat Bali (Bali Cobta). Sedangkan peran dari Dinas Sosial Kabupaten Karangasem yaitu membangun program Rumah Desaku Menanti. Program Rumah Desaku Menanti merupakan suatu ide yang berasal dari Kepala Desa Tianyar Barat yaitu Bapak Gede Agung Pasrisak Juliawan. Program Rumah Desaku Menanti ini memiliki memberikan bantuan rumah tinggal kepada mantan gepeng dan diberdayakan dalam melakukan aktivitas wisata. Aktivitas wisata tersebut diantaranya menganyam piring dari lidi, menganyam daun lontar, membuat dupa, memproduksi gula ental, mengolah kacang mete, dan aneka jenis kerajinan lainnya. Hasil kerajinan tersebut juga akan didukung oleh Dinas Sosial Kabupaten Karangasem dengan cara membantu mencarikan pangsa pasar sehingga produknya tersebut dapat berjalan secara berkelanjutan. 
Tabel 1. Matrix SWOT Strategi Pengembangan Desa Wisata Muntigunung

\begin{tabular}{|c|c|c|}
\hline \multirow[t]{2}{*}{ Internal } & Kekuatan/Strenghts (S) & $\begin{array}{l}\text { Kelemahan/Weakness } \\
\text { (W) }\end{array}$ \\
\hline & $\begin{array}{l}\text { 1. Sudah ditetapkan } \\
\text { menjadi Desa Wisata } \\
\text { Baru di Kabupaten } \\
\text { Karangasem. } \\
\text { 2. Memiliki atraksi } \\
\text { wisata trekking } \\
\text { unggulan } \\
\text { 3. Memiliki banyak } \\
\text { atraksi wisata pilihan } \\
\text { 4. Dekat dengan daerah } \\
\text { tujuan wisata pantai } \\
\text { Amed dan pantai } \\
\text { Tulamben. }\end{array}$ & $\begin{array}{l}\text { 1. Kondisi lingkungan } \\
\text { yang kotor } \\
\text { 2. Terbatasnya } \\
\text { ketersediaan air } \\
\text { bersih } \\
\text { 3. Peran masyarakat } \\
\text { lokal yang masih } \\
\text { kurang maksimal. } \\
\text { 4. Belum tersedianya } \\
\text { fasilitas toilet umum } \\
\text { dan lahan parkir }\end{array}$ \\
\hline Peluang/Opportunities (O) & Strategi SO & Strategi WO \\
\hline $\begin{array}{l}\text { 1. Banyaknya event } \\
\text { kepariwisataan di } \\
\text { Kabupaten Karangasem } \\
\text { 2. Berkembangnya } \\
\text { teknologi informasi dan } \\
\text { komunikasi. } \\
\text { 3. Berkembangnya trend } \\
\text { pariwisata dunia } \\
\text { kearah back to } \\
\text { nature/pariwisata } \\
\text { alternative }\end{array}$ & $\begin{array}{l}\text { 1. Meningkatkan strategi } \\
\text { promosi }(\mathrm{S} 1+\mathrm{S} 2+\mathrm{S} 3+\mathrm{S} 4 \text {; } \\
\mathrm{O} 1+\mathrm{O} 2+\mathrm{O} 3) \\
\text { 2. } \begin{array}{l}\text { Diversifikasi produk } \\
\text { wisata }(\mathrm{S} 1+\mathrm{S} 2 ; \mathrm{O} 2+\mathrm{O} 3)\end{array}\end{array}$ & 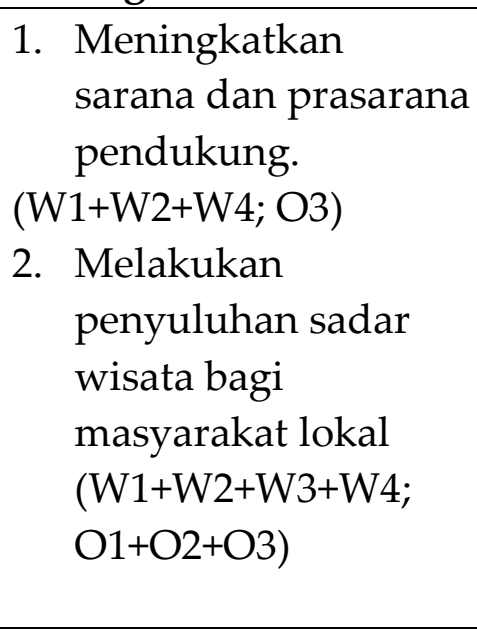 \\
\hline Ancaman/Threats $(T)$ & Strategi ST & Strategi WT \\
\hline $\begin{array}{l}\text { 1. Lokasi rawan bencana } \\
\text { Alam } \\
\text { 2. Stigma masyarakat } \\
\text { Pulau Bali sebagai desa } \\
\text { penghasil gepeng } \\
\text { 3. Perilaku buruk oknum } \\
\text { masyarakat Desa } \\
\text { Wisata Muntigunung di } \\
\text { daerah destinasi } \\
\text { pariwisata Desa Legian } \\
\text { Kuta }\end{array}$ & $\begin{array}{l}\text { 1. Mengembangkan } \\
\text { paket wisata Alternatif } \\
(\mathrm{S} 1+\mathrm{S} 2+\mathrm{S} 3 ; \mathrm{T} 1) \\
\text { 2. Menerapkan Mitigasi } \\
\text { Bencana Alam } \\
(\mathrm{S} 1+\mathrm{S} 2 ; \mathrm{T} 1)\end{array}$ & $\begin{array}{l}\text { 1. Melakukan penataan } \\
\text { dan pengelolaan } \\
\text { lingkungan } \\
(\mathrm{W} 1+\mathrm{W} 2+\mathrm{W} 4 ; \mathrm{W} 1) \\
\text { 2. Melakukan } \\
\text { pembinaan terhadap } \\
\text { masyarakat lokal } \\
(\mathrm{W} 1+\mathrm{W} 2 ; \mathrm{T} 1+\mathrm{T} 3)\end{array}$ \\
\hline
\end{tabular}

Sumber: Hasil Penelitian, 2018 


\section{e. Media}

Media pada model Pentahelix berperan sebagai expender yang mendukung publikasi dalam promosi dan membuat brand image yang dimiliki oleh Desa Wisata Muntigunung (Slamet dkk, 2017). Namun peran media yang ikut serta dalam pengembangan kepariwisataan yang ada di Desa Wisata Muntigunung sampai saat ini belum menjadi partner utama dalam mengembangkan kepariwisataan yang ada di Desa Wisata Muntigunung. Pengelola dan Pemerintah memandang bahwa keterlibatan media akan terjadi secara otomatis jika terdapat suatu acara yang terkait dengan Desa Wisata Muntigunung.

\section{Strategi Pengembangan Desa Wisata Muntigunung.}

Dalam merumuskan strategi pengembangan Desa Wisata Muntigunung harus berdasarkan hasil dari indentifikasi faktor internal dan faktor eksternal apa saja yang dimiliki oleh Desa Wisata Muntigunung. Faktor internal dan faktor eksternal tersebut kemudian akan dianalisa menggunakan teknik analisis SWOT guna memberikan strategi yang tepat terhadap strategi pengembangan Desa Wisata Muntigunung.

a. Identifikasi Faktor Internal dan Eksternal

Faktor internal yang dimiliki oleh Desa Wisata Muntigunung adalah kekuatan (strengths) dan kelemahan (weakness). Kekuatan (strengths) yang dimiliki oleh Desa Wisata Muntigunung yaitu sudah ditetapkan menjadi desa wisata baru di Kabupaten Karangasem, memiliki atraksi wisata trekking unggulan, memiliki banyak atraksi wisata pilihan, dan dekat dengan daerah tujuan wisata pantai pantai Amed dan pantai Tulamben. Sedangkan kelemhan (weakness) yang dimiliki oleh Desa Wisata Muntigunung yaitu kondisi lingkungan yang kotor, terbatasnya sumber air bersih, peran masyarakat yang kurang maksimal, dan belum tersedianya lahan parkir dan toilet umum. Faktor Ekternal yang mempengaruhi pengembangan Desa Wisata Muntigunung adalah peluang (opportunity) dan ancaman (threats). Peluang yang dimiliki dalam mengembangkan Desa Wisata Muntigunung yaitu banyaknya event 
kepariwisataan di Kabupaten Karangasem. berkembangnya teknologi informasi dan komunikasi dan berkembangnya pariwisata pedesaan. Sedangkan ancaman (threats) yang dapat mempengaruhi pengembangan Desa Wisata Muntigunung yaitu lokasi rawan bencana alam, stigma masyarakat Bali sebagai desa penghasil gepeng dan prilaku buruk oknum masyarakat Desa Wisata Muntigunung di daerah destinasi pariwisata Legian Kuta.

\section{b. Strategi Pengembangan Desa Wisata Muntigunung}

Strategi yang dapat diuraikan berdasarkan hasil indentifikasi faktor internal dan faktor eksternal yang dimiliki oleh Desa Wisata Muntigunung dapat diuraikan sebagai berikut.

1. Strategi S-O (Strenghts-Opportunity), yang pertama yaitu meningkat strategi promosi dengan program yaitu ikut berpartisipasi dalam event kepariwisataan, aktif melakukan promosi di sosial media, bekerja sama dengan industri pariwisata pantai amed dan pantai tulamben, dan bekerja sama dengan biro perjalanan wisata. Sedangkan strategi S-O yang kedua yaitu diversifikasi produk wisata $(\mathrm{S} 1+\mathrm{S} 2 ; \mathrm{O} 2+\mathrm{O} 3)$. Dengan program yaitu menyediakan fasilitas outbond saat melakukan aktivitas trekking, dan menyediakan event kebudayaan bagi para wisatawan.

2. Strategi S-T (Strenghts-Threats) yang pertama yaitu mengembangkan paket wisata alternatif. Dengan program yaitu mengembangkan paket wisata erupsi Gunung Agung, dan paket wisata menginap dengan masyarakat lokal. Sedangkan strategi S-T yang kedua yaitu menerapkan mitigasi bencana alam. Dengan program yaitu pemetaan kawasan rawan bencana, membangun petunjuk arah evakuasi, mengedukasi masyarakat lokal, dan menjaga kelestarian pohon.

3. Strategi W-O (Strenghts-Weakness) yang pertama yaitu meningkatkan sarana dan prasarana pendukung pariwisata. Dengan program yaitu membangun fasilitas toilet umum, dan membangun fasilitas lahan parkir. Sedangkan strategi W-O yang 
kedua yaitu melakukan penyuluhan sadar wisata bagi masyarakat lokal. Dengan program yaitu memperkenalkan Desa Wisata Muntigunung telah ditetapkan menjadi sebuah desa wisata baru kepada masyarakat, dan memberikan pendidikan sadar wisata bagi masyarakat lokal.

4. Strategi W-T (Weakness-Threats) yang pertama yaitu melakukan penataan dan pengelolaan lingkungan. Dengan program yaitu menyediakan lahan tempat penampungan sampah, dan mempercepat sambungan sumber air dari PDAM. Sedangkan strategi W-T yang kedua yaitu melakukan pembinaan terhadap masyarakat lokal. Dengan program yaitu memberikan pelatihan menjadi pelaku pariwisata yang benar dan menerapkan hokum adat/awig-awig.

\section{Kesimpulan}

Berdasarkan dari penjelasan bab-bab sebelumnya dapat ditarik beberapa simpulan sebagai berikut:

Pertama Desa Wisata Muntigunung yang notabene baru ditetapkan menjadi Desa Wisata di Kabupaten Karangasem oleh Pemerintah memiliki Potensi-potensi wisata yang layak untuk dikunjungi. Ada potensi wisata berdasarkan komponen daya tarik wisata 4A yaitu attraction, accessibility, amenities dan ancilliary.

Kedua peran stakeholder dalam mengembangkan Desa Wisata Muntigunung di Kecamatan Kubu Kabupaten Karangasem sudah berjalan cukup baik meskipun masih ada beberapa yang masih berjalanan. Peran stakeholder pada penelitian ini dengan menggunakan model pentahelix yang meliputi Akademisi, Bisnis, Komunitas, Pemerintah dan Media.

Ketiga Strategi Pengembangan Desa Wisata Muntigunung terdiri dari 4 strategi yang di identifikasi berdasarkan faktor internal dan faktor Ekternal berupa Strategi SO, Strategi WO, Strategi ST dan Strategi WT yang menghasilkan 7 strategi dari masing startegi tersebut. 


\section{Ucapan Terima Kasih}

Penulis mengucapkan terima kasih yang sebesar-besarnya kepada Dr. Ir. I Gusti Ayu Oka Suryawardani, M.Mgt., Ph.D. selaku Ketua Program Studi Magister Kajian Pariwisata. Penulis juga tidak lupa mengucapkan terima kasih kepada Prof. Dr. Ir Made Antara, MS. selaku pembimbing I dan Dr. I Nyoman Sukma Arida, S.Si, M.Si selaku pembimbing II yang dengan sabar dan tulus dalam memberikan bimbingan, motivasi serta senantiasa membuka wawasan berpikir kritis penulis selama dan dalam menyelesaikan penelitian tesis ini.

\section{Daftar Pustaka}

Arida, Sukma dan Antara. 2015. Panduan Pengelolaan Desa Wisata Berbasis Lokal. Denpasar : Pustaka Larasan

Cooper, John Fketcher, David Gilbert and Stephen Wanhill. (1995). Tourism, Principles and Practice. London : Logman.

Damanik, Janianton dan Helmut F. Weber. 2006. Perencanaan Ekowisata. Yogyakarta: CV Andi Offset.

Gulo, W. 2000. Metodologi Penelitian. Jakarta : PT Grasindo Anggota IKAPI

Hilyana, Siti. 2001. Dampak Pengembangan Pariwisata Terhadap Karakteristik Kultural Dan Struktural Masyarkat Lokal. Program Pasca Sarjana, Institut Pertanian Bogor

Indreswari, dkk. 2016. Mitigasi dan Penanggulangan Erupsi Bencana Gunung Api Studi Kasus Erupsi Merapi Tahun 2010. Jurnal. DIY Yogyakarta : Universitas Gajah Mada.

Isbandi Rukminto Adi. (2007). Perencanaan Partisipatoris Berbasis Aset Komunitas: dari Pemikiran Menuju Penerapan. Depok: FISIP UI Press.

Kountur, R. 2003. Metode Penelitian untuk Penulisan Skripsi dan Thesis. Jakarta: Penerbit PPM

Kusmayadi. Sugiarto, Endar. 2000. Metodologi Penelitian dalam Bidang Kepariwisataan. Gramedia Pustaka Utama: Jakarta

Madiun, I Nyoman. 2010. Nusa Dua: Model Pengembangan Kawasan Wisata Modern. Denpasar: Udayana University Press. 
Moleong, Lexy J.2007. Metologi penelitian kualitatif. Bandung: PT Remaja Rosda Karya

Pendit, I Nyoman S, 1994. Ilmu Pariwisata Sebuah Pengantar Perdana. Jakarta : PT Pradnya Paramita

Prasetyo, 2005. Pelestarian Potensi Wisata Budaya di Desa Wirun Kabupaten Sidoarjo Jawa Timur

Plog, Stanly. 2001. Way Destination Area Rise and Fall in Popularity (An Update of a Cornel Quarterly Classic), dalam Cornel Hotel and Restaurant Administration Quarterly.

Rangkuti, Freedy. 1997, Analisis SWOT : Teknik membedah kasus bisnis. Jakarta : PT. Gramedia Pustaka

Rangkuti, Freddy. 2004. The Power of Brands. Jakarta: PT. Gramedia Pustaka Utama.

Sugiama, Gima. (2013). Manajemen aset pariwisata: pelayanan berkualitas agar wisatawan puas dan loyal (1st ed.). Bandung : Guardaya Intimarta

Sugiyono. 2012 Metode Penelitian Kuantitatif, Kualitatif dan R E D, Bandung: Alfabeta

Susilo, Sri. 2008. Penilaian Ekonomi Desa Wisata Kasus : Desa Kepuharjo, Sleman, Yogyakarta, dalam Jurnal OPTIMAL Volume 6, Nomor 1.

Sukmasakti Hasworo, Ardhika. 2012. Strategi Pengembangan Objek Wisata Batik Kota Pekalongan. Skrispisi. Semarang : Universitas Diponogoro.

Suwena, Ketut. Widyatmaja, Ngurah. 2010. Pengetahuan Dasar Ilmu Pariwisata, Denpasar : Universitas Udayana.

Yoeti, Oka A. 1996. Perencanaan dan Pengembangan Pariwisata, Jakarta: Pradnya Paramita

\section{Profil Penulis}

I Wayan Adi Putra Ariawan adalah seorang mahasiswa Prodi Magister Kajian Pariwisata di Univervitas Udayana Denpasar-Bali. Ia Menyelesaikan pendidikan D4 di Sekolah Tinggi Pariwisata Nusa Dua Bali pada tahun 2012. Pada saat ini berkerja sebagai pengusaha tour and travel dan berkerja sama dengan perusahaan dari Negara Finlandia bernama Duara Travel dan memiliki konsep Stay with Local di Desa Gadungan-Tabanan, Desa Wisata Muntigunung-Karangasem dan Desa PerasiKarangasem. 
I Made Antara adalah guru besar fakultas pertanian Universitas Udayana Denpasar. Saat ini beliau mengajar dibeberapa fakultas dan program studi seperti Jurusan Sosial Ekonomi Pertanian Falkultas pertanian (PS. Agribisnis), Program Studi Magister Pariwisata, Program Doktor Pariwisata, Program Program Magister Ilmu Lingkungan dan Program Doktor Kajian Budaya.

I Nyoman Sukma Arida adalah seorang dosen kelahiran di Desa Negari Kabupaten Gianyar pada tahun 10 Juli 1975. Beliau kini mengejar di Program Studi S1 Destinasi Pariwisata, Program Magister Kajian Pariwisata S2 Fakultas Pariwisata Universitas Udayana. I Nyoman Sukma Arida menempuh pendidikan S1 di Fakultas Geografi Universitas Gajah Mada tahun 2000. Kemudian beliau melanjutkan pendidikan S2 di Universitas Udayana dengan mengambil Program Studi Ilmu Lingkungan, dan melanjutkan pendidikan S3 Program Studi Pariwisata di Universitas Gajah Mada. 